\title{
A comparison of growth and biochemical composition Mytilus galloprovincialis (Lmk.) and Mytilus edulis (L.) on the West coast of Cotentin, Normandy, France 1999-2000
}

\author{
J. Kopp ${ }^{1, *}$ F. Cornette ${ }^{2}$ and C. Simonne ${ }^{1}$
}

(1) Station de Port en Bessin, IFREMER, Avenue du Général de Gaulle, 14520 Port en Bessin, France

(2) Station de La Tremblade, IFREMER, Ronce les Bains, 17390 La Tremblade, France

*: Corresponding author : jkopp@ifremer.fr

\begin{abstract}
:
The blue mussel, Mytilus edulis has been reared along the Normandy coast line since the 1960s. The gonadal cycle of this mussel species shows a sharp decrease in meat quality during the winter period after spawning. This decline in meat quality is so severe that sales have to be suspended from December to July. Another species of mussel, Mytilus galloprovincialis, which is reared in the lagoons along the French shore of the Mediterranean Sea has a different spawning cycle. An experiment was undertaken to study the meat quality of $M$. Galloprovincialis throughout the year after the spat were transferred from the Mediterranean Sea to the Normandy coast. This species showed an immediate adaptation to the gonadal cycle of $M$. edulis. Despite suggestions from researchers, no interest was expressed to consider such transfers of $M$. galloprovincialis in the future.
\end{abstract}

Keywords: Gonadal cycle - Mytilus edulis - Mytilus galloprovincialis - Meat quality 


\section{INTRODUCTION}

Mytilids have a world-wide subtropical distribution (McDonald et al. 1991; Seed, 1992; Daguin, 2000). Two species are found in France : Mytilus edulis and Mytilus galloprovincialis.

Culture of the Pacific oyster (Crassostrea gigas), and the blue mussel Mytilus edulis is carried out in three different areas along the Normandy coast of France : the western and eastern shore of the Cotentin peninsula and the Baie des Veys (Jeanneret et al.,1992; Goulletquer et al., 1994, 1995; Kopp et al., 1991, 1997, 1998, 2000). Location of culture sites and productions of oysters and mussels in this area in 2000 are shown on fig. 1 ( Kopp et al., 2001).

The total commercial biomass of mussels was estimated to be 15,600 t (metric tons) along both coasts of the Cotentin peninsula in 2000 (Kopp et al., 2001). A biomass of 570 metric tons of mussels was estimated to exist in the Baie des Veys (Calvados, France) in 2000 (Kopp et al., 2001). These mussels are produced from natural sets of juveniles that are placed in bags and reared in this area for only a few months, (winter to fall).

Mussels breed throughout their entire life cycle along both coasts of Cotentin (Manche, France) (Goulletquer, 1995). Juveniles (spat) are collected on coconut fibre ropes at various places along the French Atlantic coast and transferred to growing areas in June. Harvest occurs one year later from July to December when meat quality is high; the spawning season occurs during winter and meat quality is so seriously depleted at that time that mussels are unsuitable for commercial markets (Lubet, 1959, 1969). This long period without commercial harvest has serious negative economic consequences for mussels farmers, especially for those who do not culture oysters along with mussels.

A few individuals of another Atlantic species of mussels, Mytilus galloprovincialis, can be found mixed in with wild mussels stocks along the coasts of Normandy (Bierne 2001). Since crosses between two species exist, the purity of these mytilids is difficult to assess (Fuentes et al.,2002). Individuals of this species are also imported unintentionally as spat on coconut ropes to the east coast on an annual basis by farmers along with $M$. edulis.

In France, $M$ galloprovincialis is cultured in lagoons and the open sea along the shore of the Mediterranean Sea and in one place of the northern coast of Brittany (Baie de Morieux) (Dardignac-Corbeil, 1979). Elsewhere in Europe and north Africa, this species is found or cultured in some Mediterranean countries including Spain (Perez Camacho, 1995; Sara, 1998), Italy (Orban et al., 2001) and Morocco (Comesana, 1998). In this Southern area, the spawning season occurs from November to December and March to April (Caceres-Martinez and Figueras, 1998), and spat recruitment is in summer in the Ria de Arousa in northwest Spain- (Molares and Fuentes, 1995). Mussels that are re-fattening between these two spawning periods, can be harvested commercially and hence commercial harvest occurs almost all year long.

This study was undertaken to compare growth of the two species and determine if commercial harvest of mussels could be achieved throughout the year in Normandy using the two species. Adaptation of $M$ galloprovincialis to environmental conditions in the Channel appeared feasible since this species possesses large physiological tolerance (Theisen, 1977; Bayne et al., 1984; Navarro et al., 1991). A preliminary experiment with this species on the east coast of Cotentin showed promising results (Goulletquer et al 1994; personal communication) . 


\section{MATERIALS AND METHODS}

Our experiment was designed to simulate commercial mussel culture practises in order that results would be relevant to the industry.

$M$. edulis seed collected on coconut fibre ropes was obtained from the Loire river estuary in June 1999. To permit growth of the seed, the ropes were held horizontally until October at one meter above the sandy bottom in the southern part of the western coast of Cotentin. This practice is employed commonly by mussel farmers in that area. (Fig 2).

M. galloprovincialis seed, similarly set on coconut fibre rope, was obtained from the breeding areas off Gruissan on the coast of the Mediterranean sea on September 26, 1999 and held in a similar manner and in the same location as M. edulis.

One month later, ropes with both mussels species were cut in $3 \mathrm{~m}$ lengths and wound on a $2 \mathrm{~m}$ high Brazilian wooden poles as shown in Fig 3. Mean total length of spat for both species was similar at that time $(30,13 \pm 4,43 \mathrm{~mm}$ for $M$. edulis and 28,31 $\pm 9,66 \mathrm{~mm}$ for $M$. galloprovincialis, $\mathrm{n}=322$ and 326 individuals respectively)

Mussels $(1.5 \mathrm{Kg})$ of both species were sampled on a monthly basis and samples were taken from the middle and outer edges of the mussel mass in order to sample the entire distribution of the population. Total length, whole weight, shell weight, fresh meat weight, freeze dried meat weight were measured. A total of 100-350 individuals were sampled depending on the dispersion of the data. This experiment ended on October 16, 2000.

Lipids (Bligh and Dyer, 1959), proteins (Lowry et al., 1951), total carbohydrates and glycogen (Dubois et al., 1956) were also assessed for both species when the monthly samples were collected. Five samples of ten mussels were collected randomly. Two sub samples were used to estimate the parameters three times.

As a result, means and variances were computed on thirty results for each species for each month for the biochemical component that were analysed.

At the end of this experiment, the yield for both species was computed. 


\section{RESULTS}

\section{Growth in total length for both species.}

Since the experiment was carried out over one year, the best fitted curve for modelling growth is close to von Bertalanffy's growth's curve. Growth in total length had a sigmoid shape as shown on Fig 4a (M. edulis) and 4b (M. gallorovincialis) (Pauly, 1997).

Other growth parameters that were modelled appeared to be well fitted to a sigmoid curve also and had the following formula :

$$
\mathrm{G}=\mathrm{a}+\mathrm{b} /(1+\exp (-(\mathrm{Nb}-\mathrm{c}) / \mathrm{d}))
$$

Where a, b, c and $\mathbf{d}$ are four constants, $\mathbf{G}$ is the growth (length, weight) reached after $\mathbf{N b}$ which is the number of days of growth.

\section{Other types of growth computed}

For all the growth curves, the computed data are shown on Table 1. Values reached by all these coefficients of determination are highly significant having a confidence of more than 99 $\%$ for all models.

\section{Growth after 385 days of rearing}

All data (or data computed after modelling) collected at the end of this experiment are shown on Table 2. Non significant differences that were observed between the observed and computed data showed the quality and type of modelling that was required.

\section{Biochemical components ratio and Lawrence \& Scott index evolutions}

Carbohydrates are used by molluscs as energy reserves that are metabolised into lipids during egg maturation. Since weight of carbohydrates and lipids did not show any significant decline during the experimental period, sigmoid curves could not be used to explain this phenomenon. In fact, the rate of change of the biochemical components ratio cycle must be studied to understand these changes.

Curves of this type are close to third degree polynomials and have the following formula ( $\mathrm{a}, \mathrm{b}, \mathrm{c}, \mathrm{d}=$ constants ; $\mathrm{R}=$ rate of biochemical component ; $\mathrm{Nb}=$ Number of days of growth) :

$$
\mathbf{R}=\mathbf{a}+\mathbf{b}(\mathrm{Nb})+\mathbf{c}(\mathrm{Nb})^{2}+\mathbf{d}(\mathrm{Nb})^{3}
$$

Each rate was computed for both species and the four biochemical components.

Computed constants and confidence levels are shown on table 3.

The slight negative values (biologically impossible) that were seen around day 100 for the total carbohydrate cycle demonstrates the model limits. However, this table shows highly significant values for carbohydrates and proteins levels for both species (99\% confidence), 
less confidence for L \& S index (95\% confidence) and no confidence for lipids which is probably correlated to highly variable conditions occurred in winter and spring (Fig. 5). No biological explanation can be given to explain these variations. Errors must have existed in the biochemical analysis that produced these false results.

\section{Comparison of growth between species}

Results at the completion of the experiment

Observed and computed data after nearly 400 days of culture are shown on table 2. $M$. edulis attained a mean shell length of approximately $45 \mathrm{~mm}$ and $M$. galloprovincialis 48.3 $\mathrm{mm}$. This difference in shell length (nearly $7 \%$ ) occurred in the other growth data : $+26 \%$ for live weight, $+19 \%$ for fresh meat weight, $+1.4 \%$ for dried meat weight and $+18 \%$ for dried shell weight. During this experiment $M$. galloprovincialis had a faster growth rate than $M$. edulis.

In contrast, there were no significant changes in proteins and lipids levels between the two species but the tend of total carbohydrate $(-28.6 \%)$, including glycogen $(-25 \%)$ was much lower in $M$. galloprovincialis.

These results show a better growth and a somewhat better meat quality for $M$. galloprovincialis compared to M. edulis.

Changes in the growth cycle during the experiment

General growth parameters showed similar changes for both species. Total length and live weight increased noticeably for both species from mid-winter to mid-summer while dried meat and their biochemical components started to increase later (mid-spring) and decreased earlier (summer). Growth appeared to slow down earlier in $M$. edulis than in $M$. galloprovincialis which was particularly evident for the dried shell weight and meat weight (fresh and dried). This indicates that $M$. edulis had a faster growth in a shorter period than $M$. galloprovincialis and that $M$. edulis had a better assimilating capacity over a wider range of environmental conditions than $M$. galloprovincialis.

Data from our work can be synthesised and presented in two figures; the total energy growth curve (Fig. 6) which groups total lipid and total carbohydrate components and the Lawrence and Scott index (Fig 7) that presents information of interest to the commercial industry. These two figures summarise all our observations. With the goal of our investigation in mind, the most important point of our work is that $M$. edulis attained a higher total energy level and had a better commercial quality than $M$. galloprovincialis during the 14 month rearing period on the west coast of Cotentin.

Cycle of biochemical components

The rapid growth rate of both species of mussels did not allow to demonstrate transfer of biochemical constituents during sexual maturation. Gonadal development occurred so quickly that it could only be observed.

As shown on Fig. 5a and Table 3, carbohydrates (including glycogen) in $M$. galloprovincialis, decreased from the beginning of the experiment until March. Minimum carbohydrate content, which was close to zero, was observed during mid-winter; at that time, 
the model computed a slight negative value but this makes no biological sense. Synthesis of carbohydrates occurred from April to August and then began to decrease again at the end of August

Accumulation of lipids showed an inverse pattern to that of carbohydrates rates with an increase until March, a decrease from March to August followed by another increase (Fig $5 b)$. mussels.

These opposed rates show the biochemical balance in relation to sexual activity in

Proteins content (Fig 5c) was similar to that of lipids with a maximum in Winter and a minimum in September.

The biochemical cycle of carbohydrates and lipids in M. edulis was similar to that in M. galloprovincialis and the same analysis can be made for this species although confidence levels are poorer.

Minimum level of carbohydrates were observed in February and maximum level in August while the maximum lipids content was in April and minimum in October.

Changes in levels of proteins were similar in both M. edulis and M. galloprovincialis.

In summary the analysis shows that both species have a similar biochemical cycle year round with a slight time lag of about one month; maximum and minimum values were slightly later for M. edulis.

\section{DISCUSSION}

This experiment was designed to assess the biological feasibility in raising two species of mussels jointly in the same area of the western coast of the Cotentin peninsula in France. Our results clearly show that $M$. galloprovincialis changed its original gonadal maturation cycle in this part of the Channel and became similar to that of M. edulis. The maturation process was similar for both species and both species attained their peak condition in quality ( $\mathrm{L} \& \mathrm{~S}$ index) and biochemical condition at the same time. Hence there was little interest in culture of $M$. galloprovincialis by the industry in this area. Growth rates of both species were similar and estimated yields of each pole showed an average difference about $10 \mathrm{Kg}(54.2 \mathrm{Kg}$ for M. edulis and $44.7 \mathrm{Kg}$ for M. galloprovincialis). The slightly better yield for M. edulis was likely due to stronger byssal attachment by this species that meant more animals remained on the substrate (the pole).

Because of this results, there is no interest by industry to raise M. galloprovincialis along this part of the French coast. Nevertheless, further experiments might determine if this species could be raised along with M. edulis in other parts of France. A second possibility is that seed of both species from other areas could be tested in Normandy as has been done in Spain (Perez Camacho et al., 1995). Another consideration is that a shift in demand to a larger sized mussel could mean a new interest in culture of $M$. galloprovincialis in this area. 


\section{REFERENCES}

Bayne B.L., Klump D.W. and Clark K.R., 1984. Aspects of feeding, including estimates of gut residence time in three mytilid species (Bivalva, Mollusca) at two contrasting sites in the Cape Peninsula, South Africa. Oecologia (Berl.), 64 : 26-33.

Bierne N. 2001. Barrières au flux génique en milieu marin : Sélection et dispersion larvaire dans la zone d'hybridation des moules côtières Mytilus edulis et M. galloprovincialis. Thèse de l’Université de Montpellier II, 220 pages.

Bligh E.G. and Dyer W.F., 1959. A rapid method of total lipid extraction and purification. Can. J. Biochem. Physiol.,37 : 911-917.

Cáceres-Martínez J. and Figueras A., 1998. Long-term survey on wild and cultured mussels (Mytilus galloprovincialis Lmk) reproductive cycles in the Ria de Vigo (NW Spain), Aquaculture, Volume 162, Pages 141-156

Comesaña A.S., Posada D. and Sanjuan A., 1998. Mytilus galloprovincialis Lmk. in northern Africa, Journal of Experimental Marine Biology and Ecology, Volume 223, Pages 271-283

Daguin, C. 2000. Phylogéographie des moules du complexe d'espèces Mytilus edulis. Université de Montpellier II.

Dardignac-Corbeil M.J., 1979 La conchyliculture française, la mytiliculture. Rev. Trav.Pêches Marit. 43, 105-130.

Dardignac-Corbeil M.J., 1989 La mytiliculture traditionnelle. Aquaculture, vol. 1, $2^{\text {ème }}$ édition. Edit. Barnabé, Techniques et documentations, Lavoisier, 288-345.

Dubois M., Gilles K.A. Hamilton J.K. Rebers P.A. and Smith F., 1956. Colorimetric method for determination of sugars and related substances. Anal.Chem., 28 : 350-356.

Fuentes J., López J.L., Mosquera E., Vázquez J., Villalba A. and Álvarez G., 2002. Growth, mortality, pathological conditions and protein expression of Mytilus edulis and M. galloprovincialis crosses cultured in the Ría de Arousa (NW of Spain), Aquaculture, In Press.

Goulletquer P., Joly J.P., Le Gagneur E., Ruelle F., 1995a. La mytiliculture dans la Manche : Biomasses en élevage et croissance de Mytilus edulis L. RIDRV - 95.01 RA/Port-en-Bessin, 83p.

Goulletquer P., Joly J.P., Le Gagneur E., Ruelle F., 1995b. Mussel (Mytilus edulis) culture management along the Normandy coastline (France): Stock assessment and growth monitoring. ICES statutory meeting 1994 Shellfish Committee C.M. 1994/K :10, 11p.

Goulletquer P., Joly J-P., Kopp J., Le Gagneur E., Moriceau J., Ruelle F., 1994. L'ostréiculture sur la côte Ouest du Cotentin. RIDRV - 94.02 RA/Port-en-Bessin, 85p. 
Jeanneret H., Kopp J., Joly J.P., Moriceau J., Legagneur E., 1992. L'ostréiculture sur la côte Est du Cotentin. Rapport RIDRV - 92.10. RA/Port-en-Bessin, 64p.

Kopp J., Joly J.P., Moriceau J., Le Gagneur E., Jacqueline F., 1991. La conchyliculture en Baie des Veys. Rapport Contrat de plan Etat-Région, 91p.

Kopp J., Joly J.P., Le Gagneur E., Ruelle F., 1997. Biomasses ostréicoles et mytilicoles en Normandie en 1995. Rapport Interne DRV/RA/LCN 97-07. RA/Port-en-Bessin, 53p.

Kopp J., Joly J.P., Le Gagneur E., Ruelle F., 1998. Atouts et contraintes de la conchyliculture normande 1 - La côte Ouest du Cotentin. Rapport Interne DRV/RA/LCN 98-03. RA/Port-en-Bessin, 240p.

Kopp J., Joly J.P., Le Gagneur E., Ruelle F., 2000. Atouts et contraintes de la conchyliculture normande 2 - La côte Est du Cotentin. Rapport Interne DRV /RA/LCN 2000-57. RA/Port-en-Bessin, 205p.

Kopp J., Messian G., Le Gagneur E., Cornette F., Ropert M., 2001. Etat des stocks conchylicoles normands en 2000. Rapport Interne DRV /RA/LCN 2001-08. RA/Port-enBessin, 52p.

Lowry O.H., Rosebrough N., Farr A.L. and Randall R .J., 1951. Protein measurement with the folin phenol regent. J. Biol. Chem., 193 : 265-275.

Lubet P., 1959. Recherche sur le cycle et l'émission des gamètes chez les mytilidés et les pectinidés . Rev. Trav.Pêches Marit. 23, 297-308.

Lubet P., 1969. Biologie et exploitation des moules. La Pêche Maritime. 1001 : 947-952.

McDonald, J.H., Seed R. and Koehn R.K. 1991. Allozymes and morphometric characters of three species of Mytilus in the Northern and Southern hemispheres. Marine Biology 111 ; 323-333

Molares J. and Fuentes J. 1995, Recruitment of the mussel Mytilus galloprovincialis on collectors situated on the intertidal zone in the Ría de Arousa (NW Spain), Aquaculture, Volume 138, Issues 1-4, 15 December 1995, Pages 131-137

Navarro E., Iglesias J.I.P., Pérez Camacho, Labarta U. and Beiras R. 1991. The physiological energetics of mussels (Mytilus galloprovincialis Lmk) from different cultivation rafts in the Ria de Arosa (Galicia, N.W. Spain). Aquaculture, 94 ; 197-212.

Orban E., Di Lena G., Nevigato T., Casini I., Marzetti A. and Caproni R. 2002, Seasonal changes in meat content, condition index and chemical composition of mussels (Mytilus galloprovincialis) cultured in two different Italian sites, Food Chemistry, Volume 77, Issue 1, May 2002, Pages 57-65.

Pauly D. 1997, Méthode pour l'évauation des ressources halieutiques Cépaduès-editions Collection POLYTECH 288p. 
Perez Camacho A., Labarta U. and Beiras R. 1995, Growth of mussels (Mytilus edulis galloprovincialis) on cultivation rafts: influence of seed source, cultivation site and phytoplankton availability, Aquaculture, Volume 138, Issues 1-4, 15 December 1995, Pages 349-362.

Sarà G., Manganaro A., Cortese G., Pusceddu A. and Mazzola A., 1998. The relationship between food availability and growth in Mytilus galloprovincialis in the open sea (southern Mediterranean), Aquaculture, Volume 167, Pages 1-15.

Seed, R. 1992. Systematics, evolution and distribution of mussels belonging to the genus Mytilus : an overview. American Malacological Bulletin 9 : 123-137.

Thiesen B.F., 1977. Feeding rate of Mytilus edulis (Bivalvia) from different part of Danish waters in water of different turbidity. Ophelia, $16: 221-232$. 


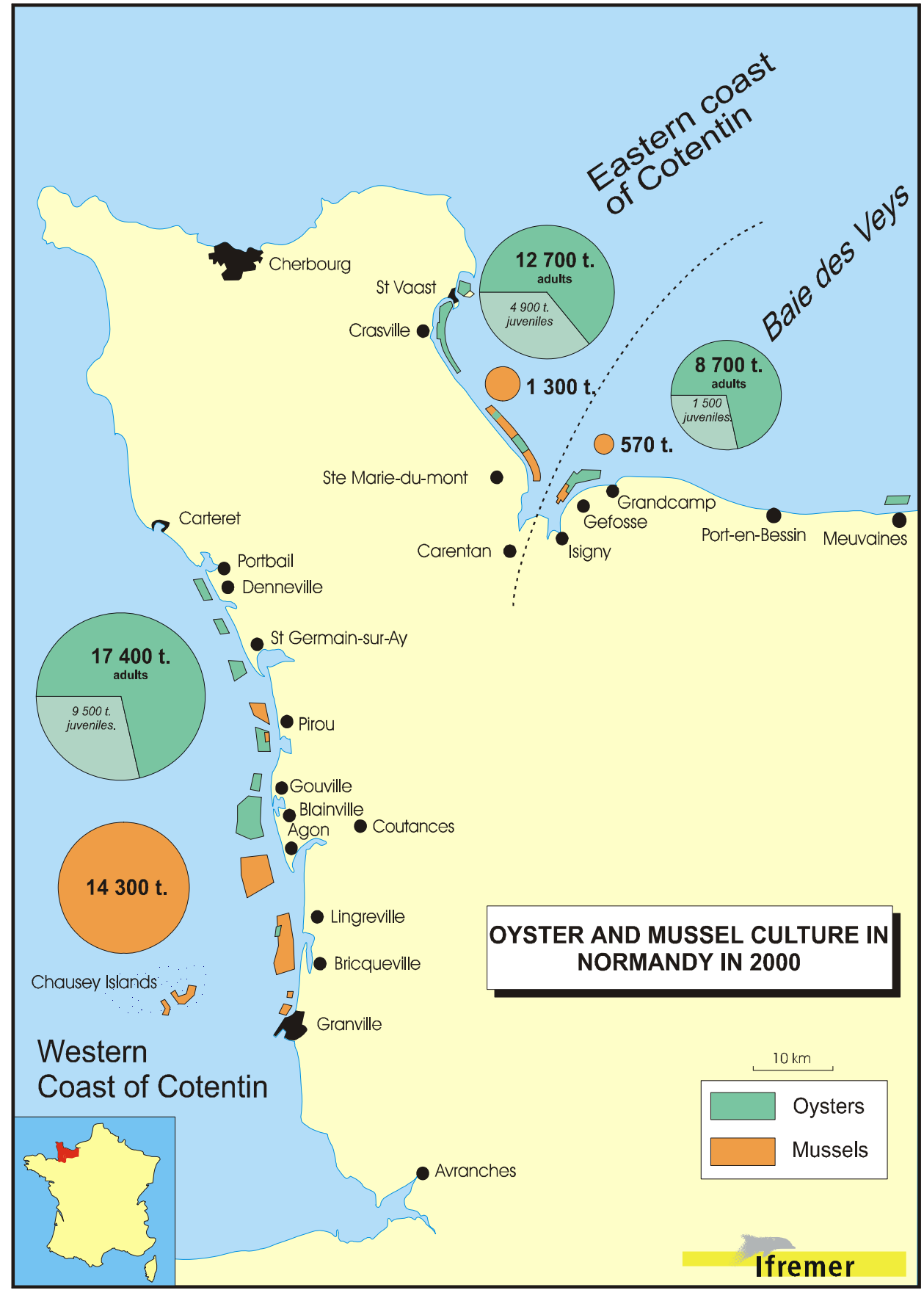

Fig. 1 : Map of the coastal area of Normandy, France showing the location of shellfish culture sites and the production of oysters and mussels in 2000. 


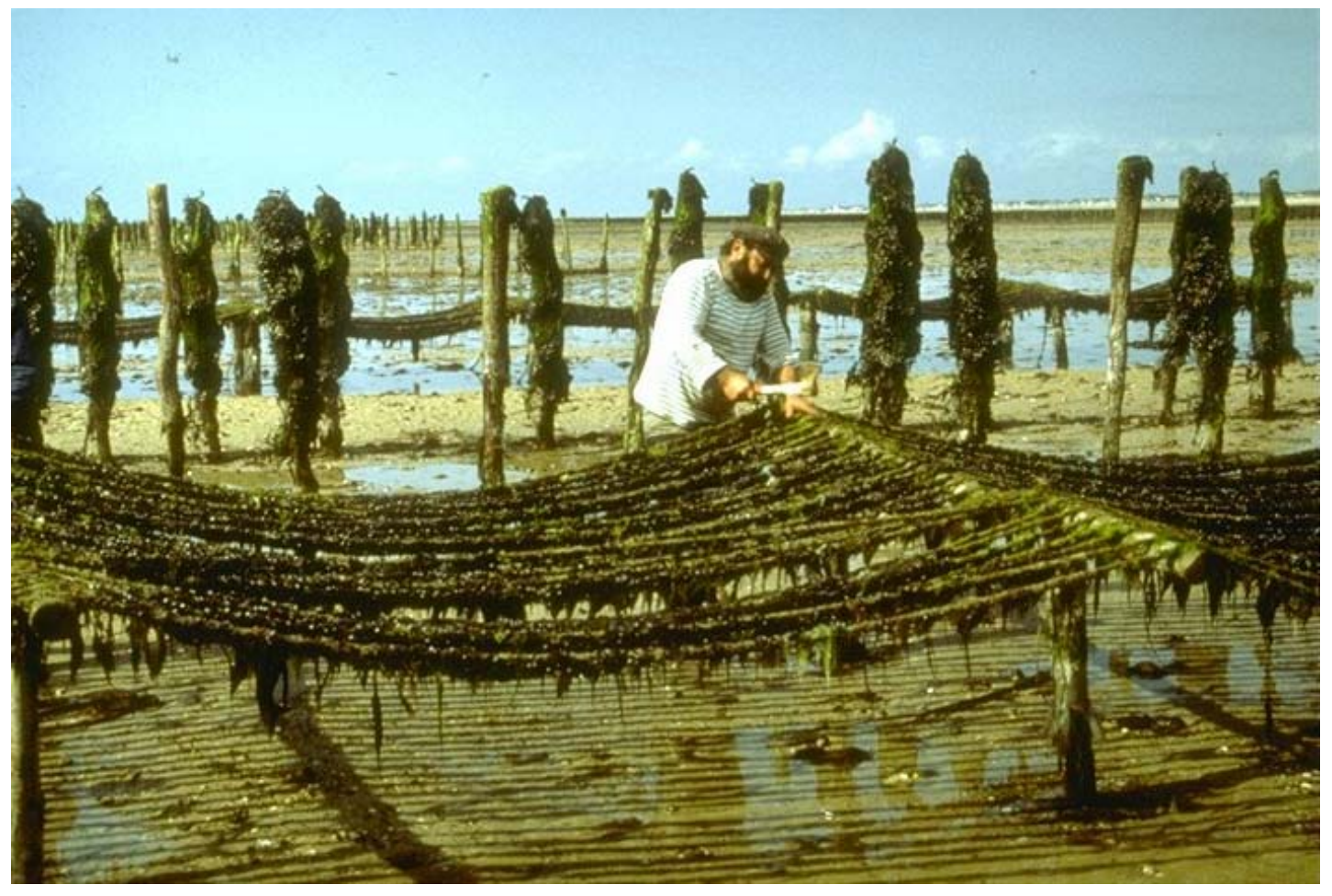

Fig. 2 : Coconut fibre ropes used to collect mussels seed.

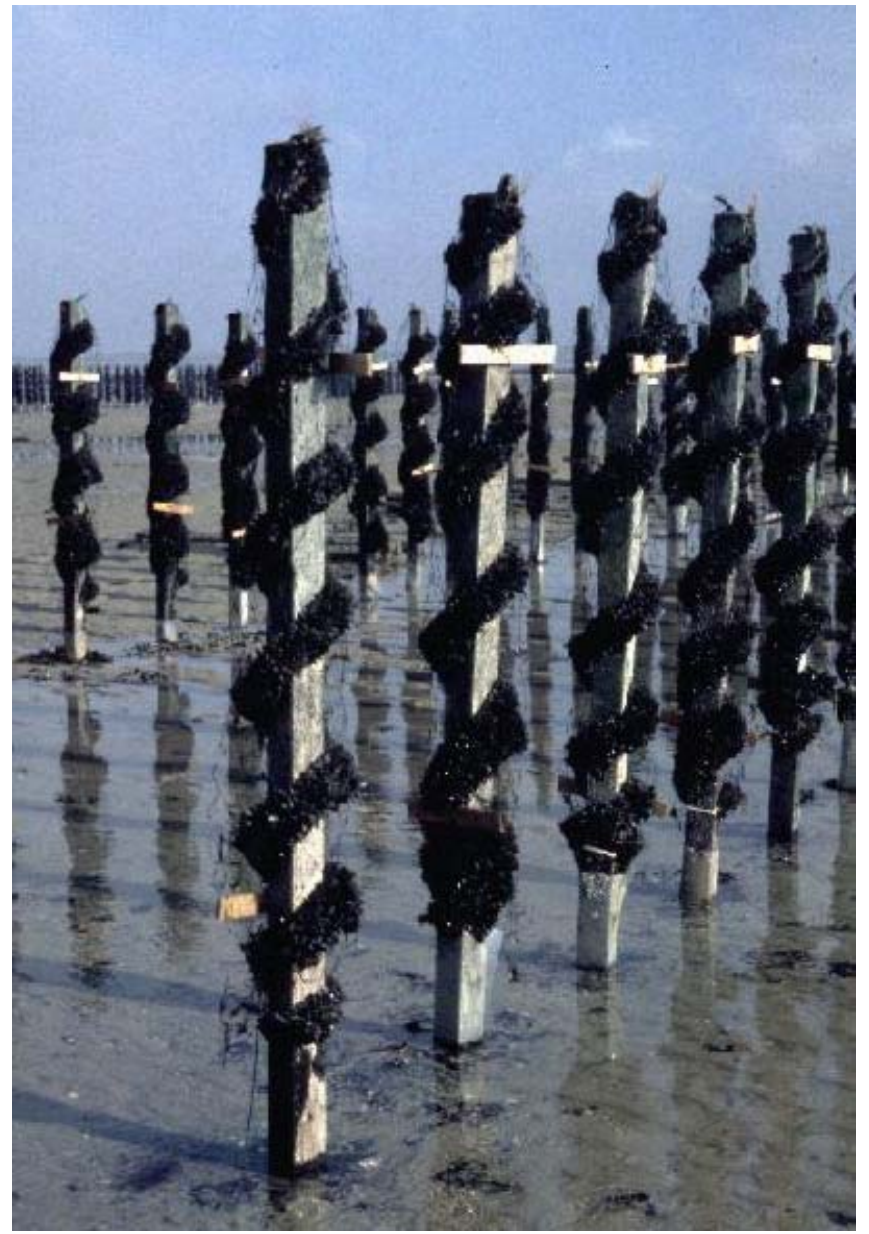

Fig. 3 : Brazilian wooden poles with mussels attached to them for grow out, October 27,1999. 
M. edulis : Length growth

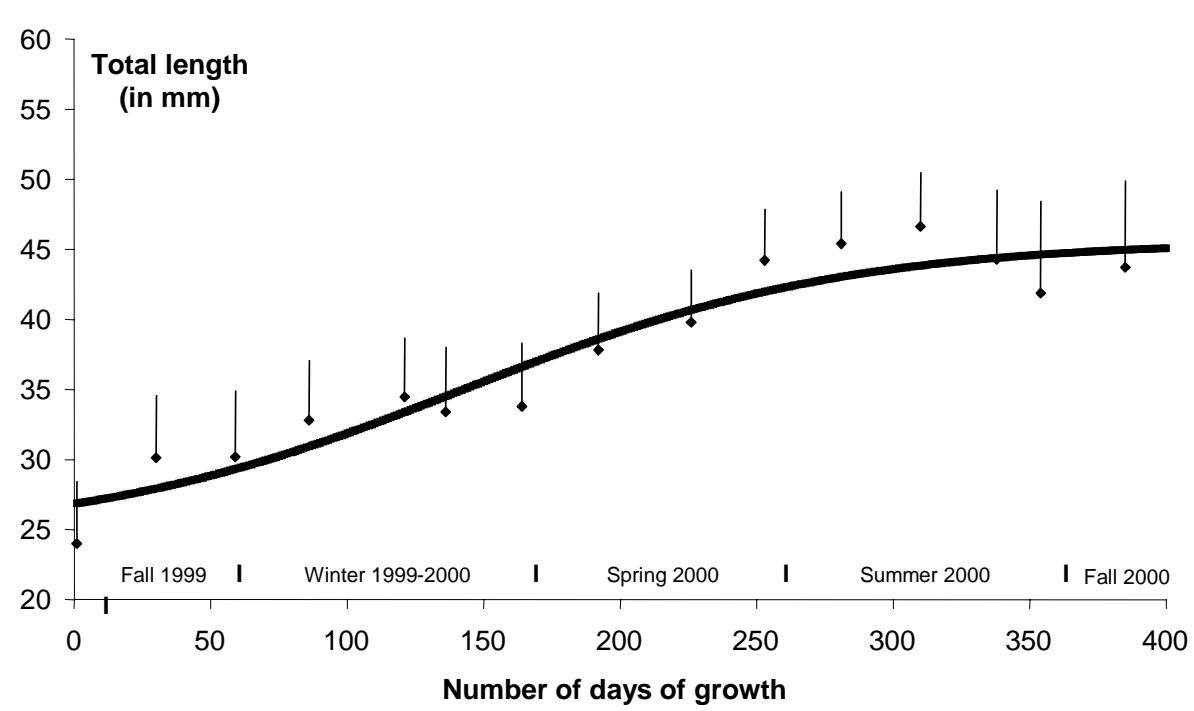

Fig 4a : Growth of $M$. edulis in shell length during the experimental period, 19992000.

M. galloprovincialis : Length growth

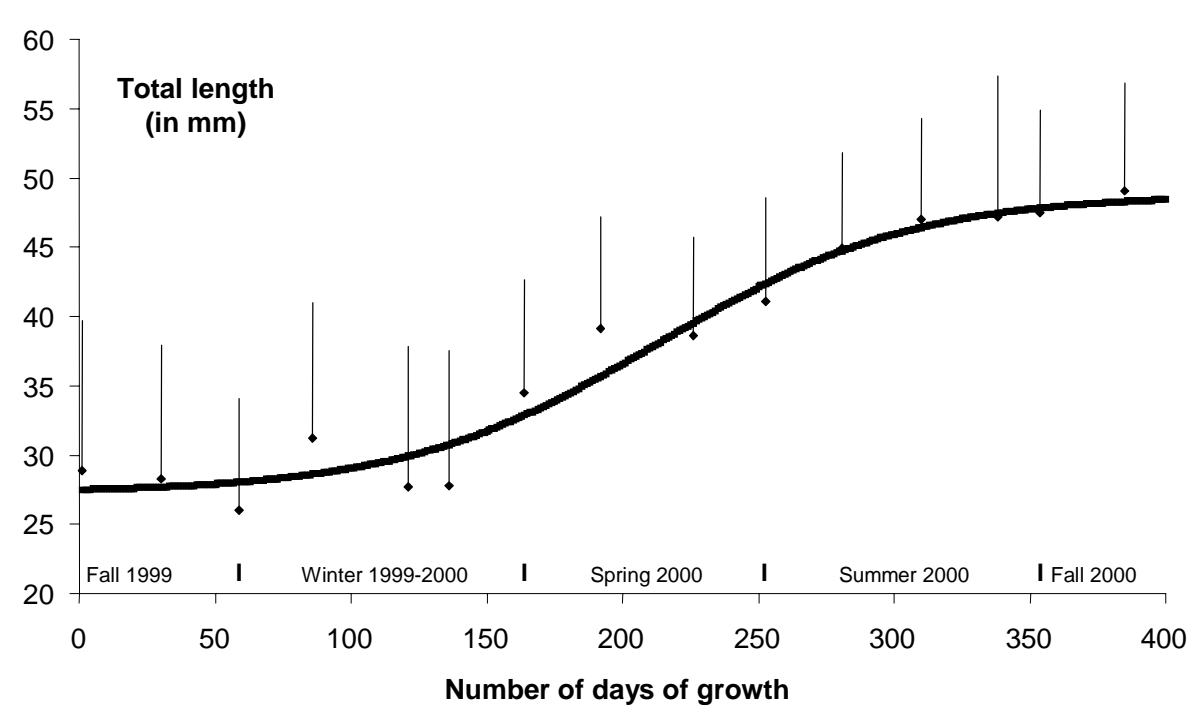

Fig 4b : Growth of $M$. galloprovincialis in shell length during the experimental period, 1999-2000. 
M. galloprovincialis : Total carbohydrates rate evolution

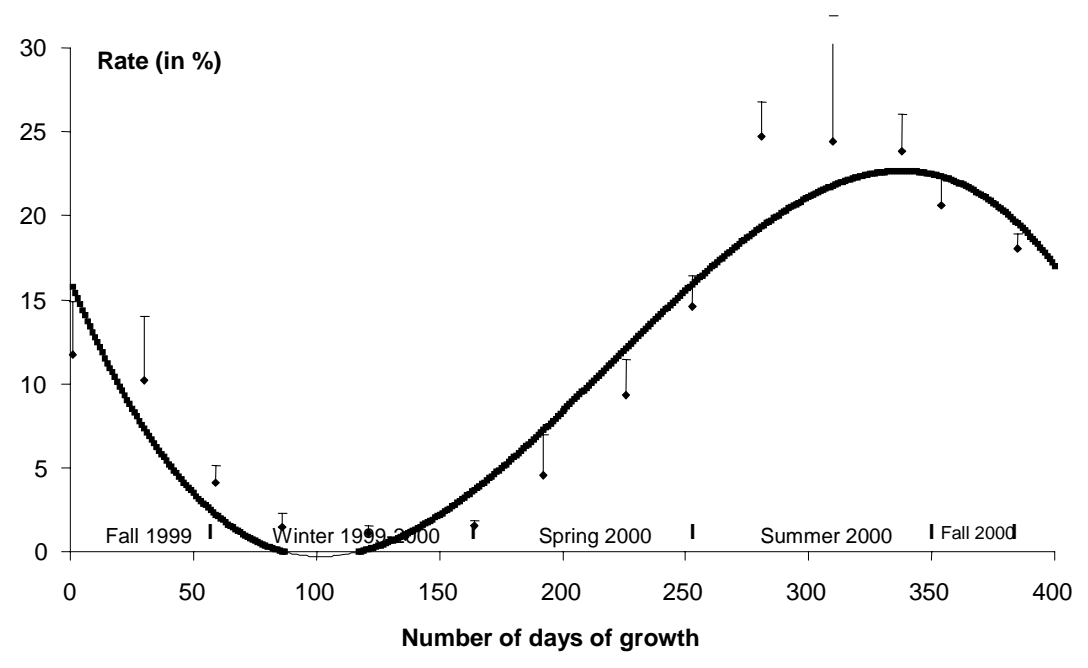

Fig 5a : Cycle of total carbohydrates in M. galloprovincialis_during the experimental period, 1999-2000.

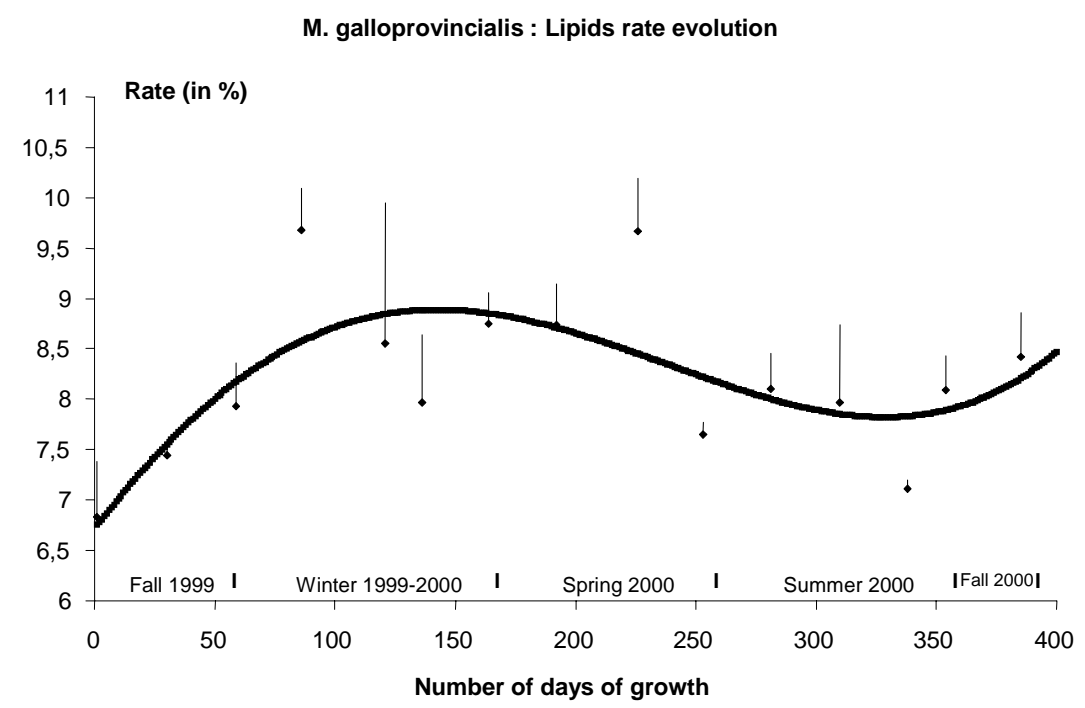

Fig 5b : Cycle of lipids in M. galloprovincialis_during the experimental period, 1999-2000.

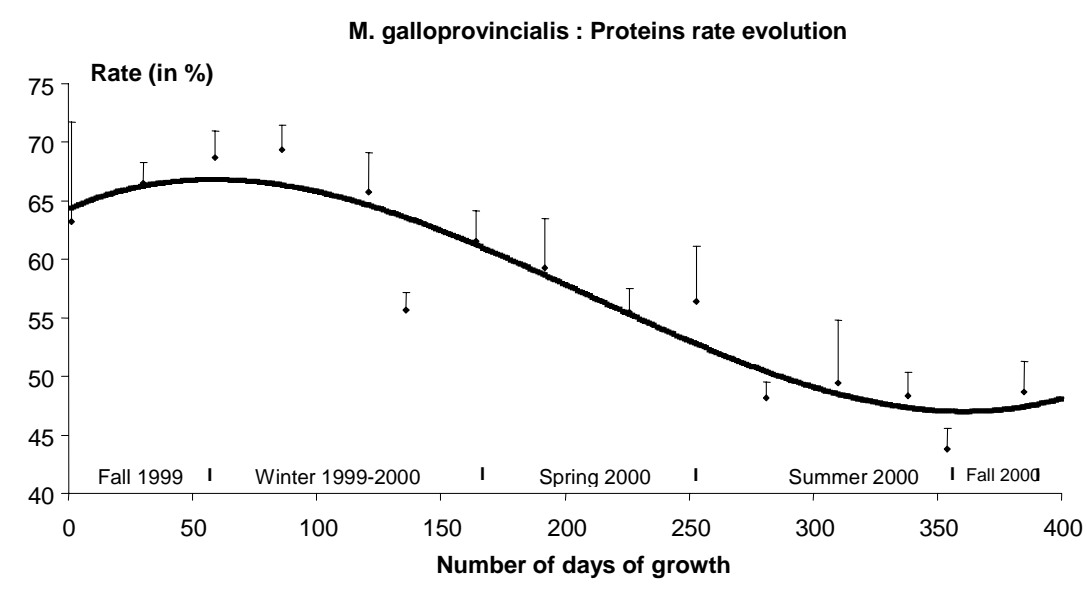

Fig 5c : Cycle of proteins in M. galloprovincialis_during the experimental period, 1999-2000. 


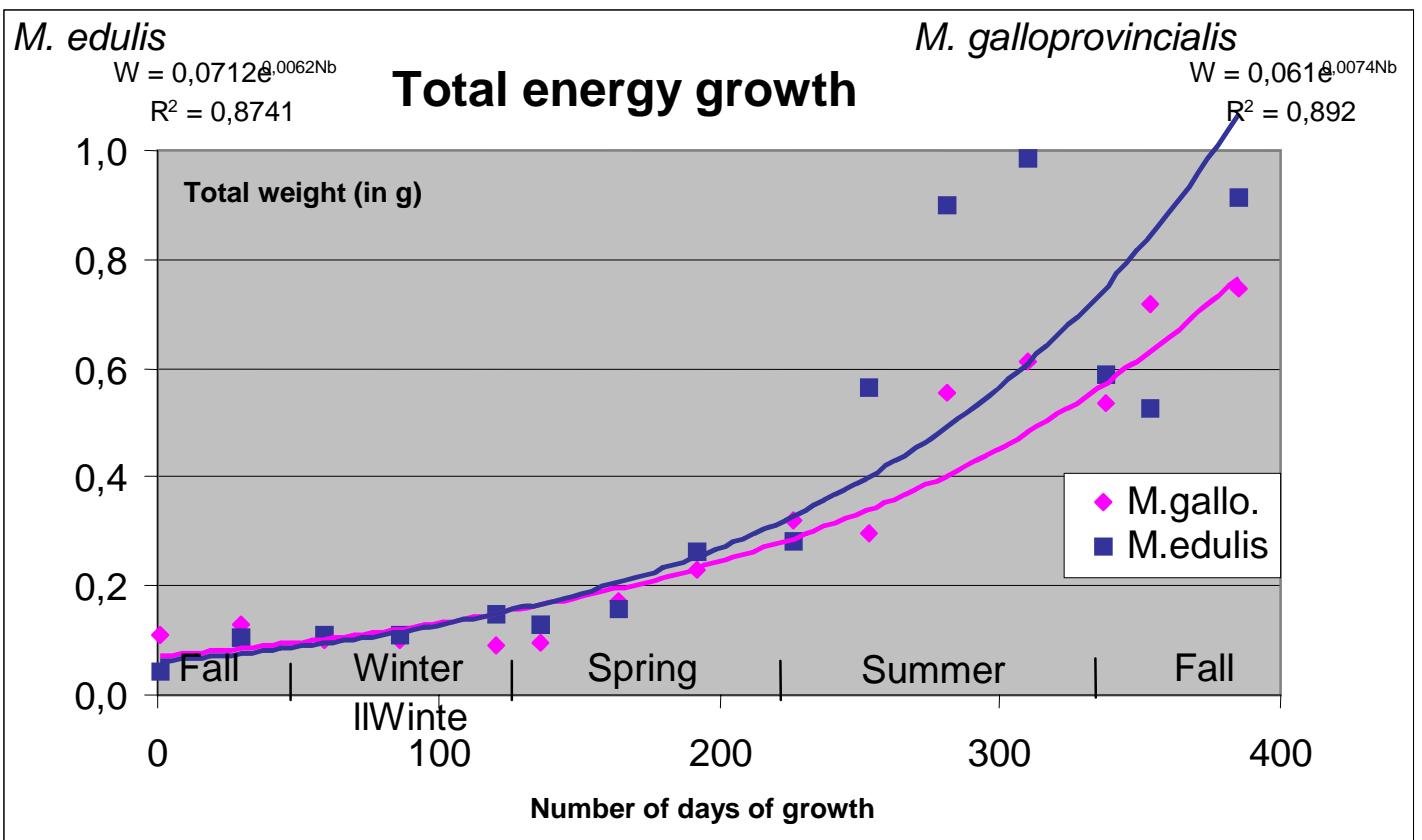

Fig. 6 : Measured total energy content for both species during the experimental period, 19992000.

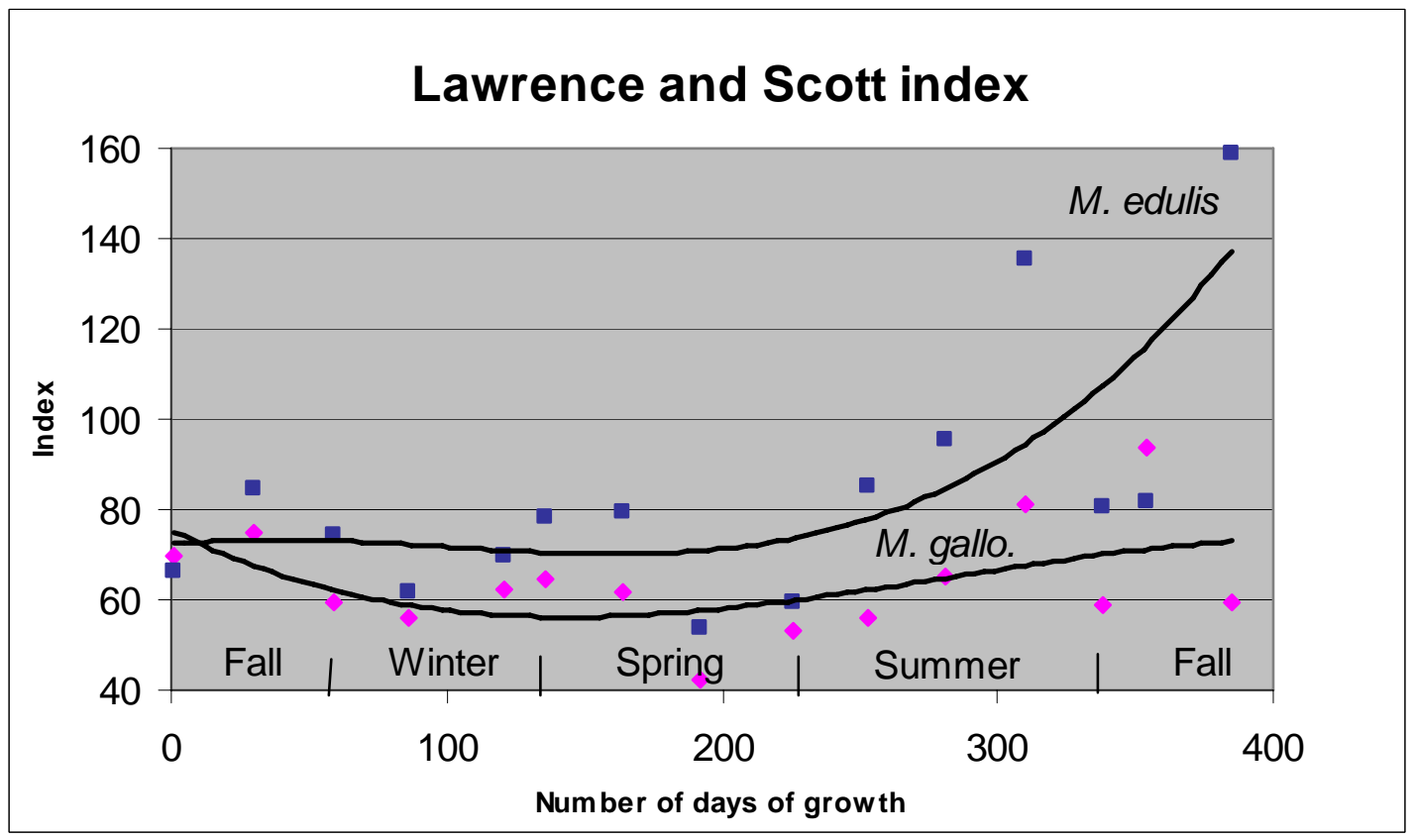

Fig 7 : The Lawrence and Scott index for both species during the experimental period, 19992000. 
Table 1 : Parameters, values of constants and coefficient of determination for modelled growth curves (length and weight), for both species.

\begin{tabular}{|c|l|c|c|c|c|c|}
\hline $\begin{array}{c}\text { Type of growth } \\
\text { computed }\end{array}$ & \multicolumn{1}{|c|}{ Measure } & $\mathbf{R}^{2}$ & $\mathbf{a}$ & $\mathbf{b}$ & $\mathbf{c}$ & $\mathbf{d}$ \\
\hline \multirow{4}{*}{$\begin{array}{l}\text { Length } \\
\end{array}$} & Overall M. edulis & 0,91 & 24,39 & 21,25 & 141,49 & 70,08 \\
\cline { 2 - 7 } & Overall M. galloprovincialis & 0,96 & 27,29 & 21,57 & 212,09 & 46,78 \\
\hline \multirow{5}{*}{ Weight } & Total M. edulis & 0,93 & 2,24 & 5,94 & 214,71 & 37,49 \\
\cline { 2 - 7 } & Total M. galloprovincialis & 0,97 & 2,38 & 9,36 & 252,54 & 54,37 \\
\cline { 2 - 7 } & Dried shell M. edulis & 0,94 & 0,79 & 2,20 & 216,95 & 30,82 \\
\cline { 2 - 7 } & Dried shell M. galloprovincialis & 0,97 & 0,96 & 2,84 & 259,35 & 45,02 \\
\cline { 2 - 7 } & Fresh meat M. edulis & 0,94 & 0,67 & 1,90 & 228,31 & 23,40 \\
\cline { 2 - 7 } & Fresh meat M. galloprovincialis & 0,97 & 0,57 & 3,36 & 299,44 & 69,04 \\
\cline { 2 - 7 } & Dried meat M. edulis & 0,95 & 0,14 & 0,57 & 241,57 & 13,18 \\
\cline { 2 - 7 } & Dried meat M. galloprovincialis & 0,97 & 0,12 & 0,65 & 271,06 & 46,40 \\
\cline { 2 - 7 } & Proteins M. edulis & 0,93 & 0,084 & 0,259 & 238,35 & 18,40 \\
\cline { 2 - 7 } & Proteins M. galloprovincialis & 0,97 & 0,076 & 0,282 & 265,05 & 49,31 \\
\cline { 2 - 7 } & Lipids M. edulis & 0,87 & 0,012 & 0,047 & 237,36 & 13,98 \\
\cline { 2 - 7 } & Lipids M. galloprovincialis & 0,95 & 0,007 & 0,066 & 293,87 & 69,05 \\
\cline { 2 - 7 } & Total carbohydrates M. edulis & 0,82 & 0,010 & 0,175 & 249,67 & 8,51 \\
\cline { 2 - 7 } & Total carbohydrates M. gall. & 0,99 & 0,008 & 0,132 & 260,10 & 9,82 \\
\cline { 2 - 7 } & Glycogen M. edulis & 0,86 & 0,009 & 0,140 & 237,06 & 1,10 \\
\cline { 2 - 6 } & Glycogen M. galloprovincialis & 0,97 & 0,004 & 0,114 & 259,05 & 16,01 \\
\hline
\end{tabular}

Table 2 : Measured and computed measures of growth for both species after 385 days of rearing. $(\mathbf{g} / \mathbf{e})=$ galloprovincialis/edulis

\begin{tabular}{|c|c|c|c|c|c|c|c|}
\hline & \multicolumn{3}{|c|}{ Mytilus edulis } & \multicolumn{3}{|c|}{ Mytilus galloprovincialis } & \multirow{2}{*}{$\begin{array}{c}\text { Difference } \\
\text { in \% } \\
\text { (g/e) * }\end{array}$} \\
\hline & Measured & $\mathbf{R}^{2}$ & Computed & Measured & $\mathbf{R}^{2}$ & Computed & \\
\hline Overall length (mm) & 43,73 & 6,13 & 45,00 & 49,04 & 7,82 & 48,33 & $+6,89$ \\
\hline Total fresh weight (g) & 7,8 & 3,44 & 8,12 & 10,84 & 4,46 & 10,98 & $+26,05$ \\
\hline Dried shell weight (g) & 2,85 & 1,07 & 2,98 & 3,50 & 1,36 & 3,63 & $+17,91$ \\
\hline Fresh meat weight( g) & 2,62 & 0,12 & 2,57 & 3,14 & 0,44 & 3,18 & $+19,18$ \\
\hline Dried meat weight (g) & 0,77 & 0,04 & 0,71 & 0,73 & 0,09 & 0,72 & $+1,39$ \\
\hline Proteins weight(g) & 0,36 & 0,035 & 0,34 & 0,36 & 0,019 & 0,34 & 0,00 \\
\hline Lipids weight (g) & 0,07 & 0,008 & 0,06 & 0,06 & 0,003 & 0,06 & 0,00 \\
\hline Total carbohydrates w. (g) & 0,23 & 0,012 & 0,18 & 0,13 & 0,006 & 0,14 & $-28,57$ \\
\hline Glycogen weight (g) & 0,16 & 0,021 & 0,15 & 0,12 & 0,007 & 0,12 & $-25,00$ \\
\hline
\end{tabular}


Table 3 : Parameters, constants and coefficient of determination of biochemical components and Lawrence and Scott index measured for both species during the experiment.

\begin{tabular}{|c|c|c|c|c|c|c|}
\hline Specie & Measure & $\mathbf{R}^{2}$ & $\mathbf{a}$ & $\mathbf{b}$ & $\mathbf{C}$ & $\mathbf{d}$ \\
\hline \multirow{4}{*}{ Mytilus edulis } & Carbohydrates & 0,67 & 15,8308 & $-0,2554$ & 0,0016 & $-2.35 \mathrm{e}-06$ \\
\cline { 2 - 7 } & Glycogen & 0,77 & 14,1176 & $-0,2839$ & 0,0019 & $-2.98 \mathrm{e}-06$ \\
\cline { 2 - 7 } & Lipids & 0,40 & 6,8325 & 0,0203 & $-4,5538$ & $-1.61 \mathrm{e}-09$ \\
\cline { 2 - 7 } & Proteins & 0,75 & 47,7864 & 0,3771 & $-0,0024$ & $3.70 \mathrm{e}-06$ \\
\cline { 2 - 7 } & L \& S & 0,54 & 72,2658 & 0,0590 & $-0,0010$ & $3.00 \mathrm{e}-06$ \\
\hline \multirow{4}{*}{$\begin{array}{c}\text { Mytilus } \\
\text { gaprovincialis }\end{array}$} & Carbohydrates & 0,92 & 15,7832 & $-0,3547$ & 0,0023 & $3.49 \mathrm{e}-06$ \\
\cline { 2 - 7 } & Glycogen & 0,92 & 10,0020 & $-0,2424$ & 0,0016 & $-2.39 \mathrm{e}-06$ \\
\cline { 2 - 7 } & Lipids & 0,49 & 6,7532 & 0,0297 & $-1,6710$ & $6.77 \mathrm{e}-07$ \\
\cline { 2 - 7 } & Proteins & 0,89 & 64,4188 & 0,0886 & $-0,0009$ & $1.43 \mathrm{e}-06$ \\
\cline { 2 - 7 } & L \& S & 0,57 & 75,4357 & $-0,3019$ & 0,0014 & $-2.00 \mathrm{e}-06$ \\
\hline
\end{tabular}

